Reprod. Nutr. Dévelop. 1980, 20 (1 A), 1-21.

\title{
Vitellogenin, the extraovarian precursor of the protein yolk in Crustacea : A review
}

\author{
by J. J. MEUSY
}

\author{
Laboratoire de Sexualité ef Reproduction des Invertébrés, ERA 409, \\ Université Pierre et Marie Curie, \\ 4, place Jussieu, 75230 Paris cedex 05, France
}

\begin{abstract}
Summary. This article reviews our knowledge of crustacean vitellogenin and its role in vitellogenesis. Besides the biochemical and immunological aspects, particular attention has been given to hormonal control of the synthesis of this yolk precursor. Some examples from insects, amphibians and birds are compared.
\end{abstract}

\section{Introduction.}

When released from the female, the egg carries with it not only genetic information programming its future development, but also metabolic stores, or the yolk, which are very abundant in many groups. The first aspect straightway held the attention of researchers, whereas the study of the mechanisms of yolk formation began only much later. For a long time it was thought that the proteinaceous yolk was synthesized only by the oocyte from amino acids of the hemolymph. This concept seemed to especially apply to the less evolved groups, but as concerned the Arthropoda and non-mammalian vertebrates, it was attacked in the 1950's in some precursor studies, e.g. work on the silkworm by Telfer (1954), and that attack intensified from 1960 on. In myriapods, crustaceans, insects, fish, amphibians and birds it was shown that a lipoprotein complex or "vitellogenin » was prerequisite to the constitution of the protein yolk, and that this vitellogenin was often associated with other prosthetic groups and synthesized outside the ovary, vehicled by the blood and sequestered by the oocytes during vitellogenesis owing to a mechanism of endocytosis (micropinocytosis) (see review in Busson-Mabillot, 1969). Thus, arriving in the oocytes in a more or less modified form, the vitellogenin constituted a large part of the proteinaceous yolk.

The existence of a female-specific serum protein was reported in crustaceans for the first time by Frentz (1960) in the crab, Carcinus maenas. This was confirmed, and its relations with vitellogenesis were studied, e.g. in the shrimp, Atyaephyra desmaresti (Descouturelle and Frentz, 1967), the crab, Paratelphusa hydrodromous (Adiyodi, 1968a), the isopods, Porcellio dilatatus and Ligia oceanica (Besse and Mocquard, 1968), the amphipod, Orchestia gammarella (Meusy, Charniaux-Cotton and Croisille, 1969) and the crab, Callinectes sapidus (Kerr, 1969). A complete bibliography of early works has been compiled by Gibert (1972). 


\section{Ultrastructural changes during growth of the oocyte.}

The development of the crustacean oocyte comprises fwo stages which are distinguished by completely different metabolic and hormonal mechanisms (Meusy, 1963 ; Balesdent, 1965). Early growth, called previtellogenesis, occurs both during the period of sexual activity and that of sexual rest. In the amphipod, Orchestia gammarella, the oocyte, blocked in meiotic prophase, increases in diameter from $18 \mu \mathrm{m}$ at the onset of previtellogenesis to $150-160 \mu \mathrm{m}$ at the end of it. The number of ribosomes and polyribosomes first increases in the cytoplasm and then small PAS-positive granules of a glycoprotein type gradually accumulate (Zerbib, 1976). Electron microscopy showed that these granules were ergastoplasmic vesicles formed from the rough endoplasmic reticulum. This phase was thus mainly characterized by endogenous syntheses and could be called autosynthetic, even if there was a slight micropinocytosis towards its end (Zerbib, 1973, 1978). Several authors (Dhainaut and de Leersnyder, 1976a ; Charniaux-Cotton, 1978) have wished to retain the term « previtellogene-

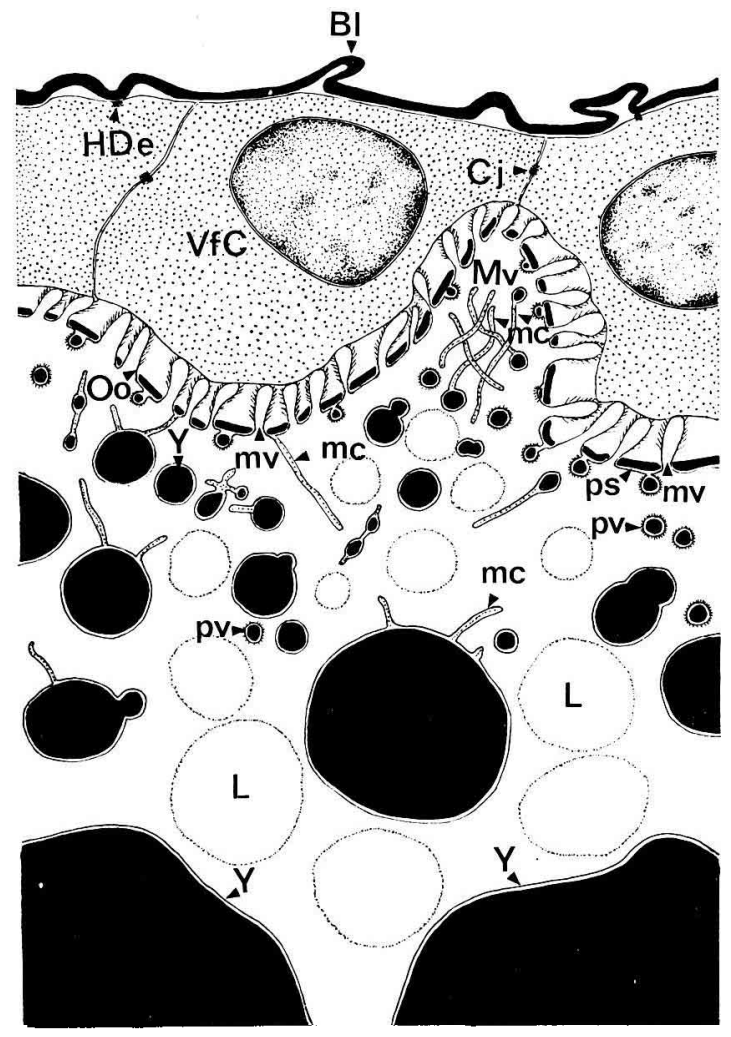

FIG. 1. - Pinocytosis and yolk body formation in the oocyte of Orchestia gammarella (from Zerbib, 1978). BI : basement lamina ; $\mathrm{Cj}$ : cell junction ; HDe : hemidesmosome ; L : lipid globule ; mc : microcanaliculus; $\mathrm{Mv}$ : macrovillus ; $\mathrm{mv}$ : microvillus ; 00 : oolemma ; ps : perivitellin space ; pv : pinocytotic vesicle ; VfC : vitellogenic follicle cell ; $Y$ : yolk body. 
sis » for the period of ribosome and polyribosome accumulation and call the period of glycoprotein granule accumulation «primary vitellogenesis ». However, there is no clear boundary between the two periods. Analogous observations have been reported for other crustaceans : the crayfish (Beams and Kessel, 1962, 1963), the decapod, Libinia emarginata (Hinsch and Cone, 1969), the crab, Cancer pagurus (Eurenius, 1973) and the crab, Eriocheir sinensis (Dhainaut and de Leersnyder, 1976b).

The second period of oocyte growth, or vitellogenesis strictly speaking (« secondary vitellogenesis " according to the terminology of Dhainaut and de Leersnyder, 1976 ; Charniaux-Cotton, 1978), only occurs during reproduction. In crustaceans this phase is mainly heterosynthetic : the yolk is constituted from a lipoprotein complex - vitellogenin - present in the hemolymph and sequestered by the oocytes. The oocytes of 0 . gammarella increase from 150-160 $\mu \mathrm{m}$ at the onset of vitellogenesis, to about $800 \mu \mathrm{m}$ at egg-laying, and soon acquire a violet color. Important changes occurring at the oocyte surface at the onset of vitellogenesis have been described by Zerbib $(1973,1978)$ in 0 . gammarella (fig. 1). The plasmic membrane developed many microvilli, which until then were few in number; these traversed the vitellin envelope of the oocyte, coming into contact with the follicular cells. Moreover, macrovilli 2 to $15 \mu \mathrm{m}$ high formed all around the circumference of the oocyte ; these micro and macrovilli considerably increased the oocyte surface and probably its exchange potential. At the same time, endocytosis assumed great importance. The plasmic membrane invaginated and formed many small «buds » which finally detached and became pinocytotic vesicles. A system of small ducts (microcanaliculi) in the cortical ooplasm and especially in the macrovilli, drained the contents of the pinocytotic vesicles and formed the yolk bodies having a lipoglyco-carotenoprotein content. These bodies increased in size by fusion, and were gradually pushed towards the center of the oocyte. At the end of this modification, they formed the polyedric yolk platelets measuring 10 to $50 \mu \mathrm{m}$. During vitellogenesis, the number of lipid globules (triglycerides) increased; their origin was unknown.

At the end of vitellogenesis, the macrovilli regressed completely and the microvilli retracted. A new type of yolk enclave, the cortical granules, then appeared near the oocyte surface; their role was not well known. When the oocyte was mature and ready to be laid, it was perfectly smooth and had lost all contact with the follicular cells.

Except for the presence of macrovilli (which have only been described in O. gammarella so far as we know), the main lines of vitellogenesis are analogous in the other crustaceans studied and mentioned above. However, Kessel and his collaborators (Beams and Kessel, 1963 ; Kessel, 1968a, b ; Ganion and Kessel, 1972) seemed to attribute a minimal role to pinocytosis in the constitution of the crayfish yolk. In fact, those authors did not indicate the developmental stage of the oocytes studied. Zerbib (1978) was probably right when he remarked that those oocytes would not be in vitellogenesis, if judged by their size. Thus, it is understandable why Kessel and his collaborators only reported minute pinocytosis. The recent observations of Zerbib (1979) on the crayfish, Astacus astacus and A. leptodactylus, as well as on the shrimp, Lysmata seticaudata (personal communication), confirmed those on the 0 . gammarella oocyte. 
Ultrastructural study alone could leave a doubt about the direction of the exchange occurring between the oocyte and its surrounding medium. Although the mode of yolk body formation favored endocytosis, the possibility of exocytosis could not be excluded. Thus, Wolin, Laufer and Albertini (1973) cultured ovarian fractions of the crab, Uca pugilator, and the crayfish, Cambarus clarkii, in the presence of vitellogenin (called «lipovitellin » by those authors) which they conjugated with fluoresceine isothiocyanate. During vitellogenesis the oocytes fluoresced clearly, while those in previtellogenesis or at the end of vitellogenesis did not fluoresce. It should be noted that the method of isolating vitellogenin by ammonium sulfate precipitation offered no guarantee of purity, as Lui and $O^{\prime}$ Connor (1976) remarked. At the ultrastructural level, Zerbib (1977) studied the micropinocytotic uptake of peroxidase by the 0 . gammarella oocyte. The reality of endocytosis has also been shown in insects, amphibians, birds and fish (see review in Busson-Mabillot, 1969). In all these groups, the general outline of the mode of yolk body formation was analogous to that described in 0 . gammarella. Some species of Anoura were an exception (Lanzavecchia, 1961 ; Ward, 1962, 1964 ; Balinsky and Devis, 1963) since the mitochondria in those animals played a major role.

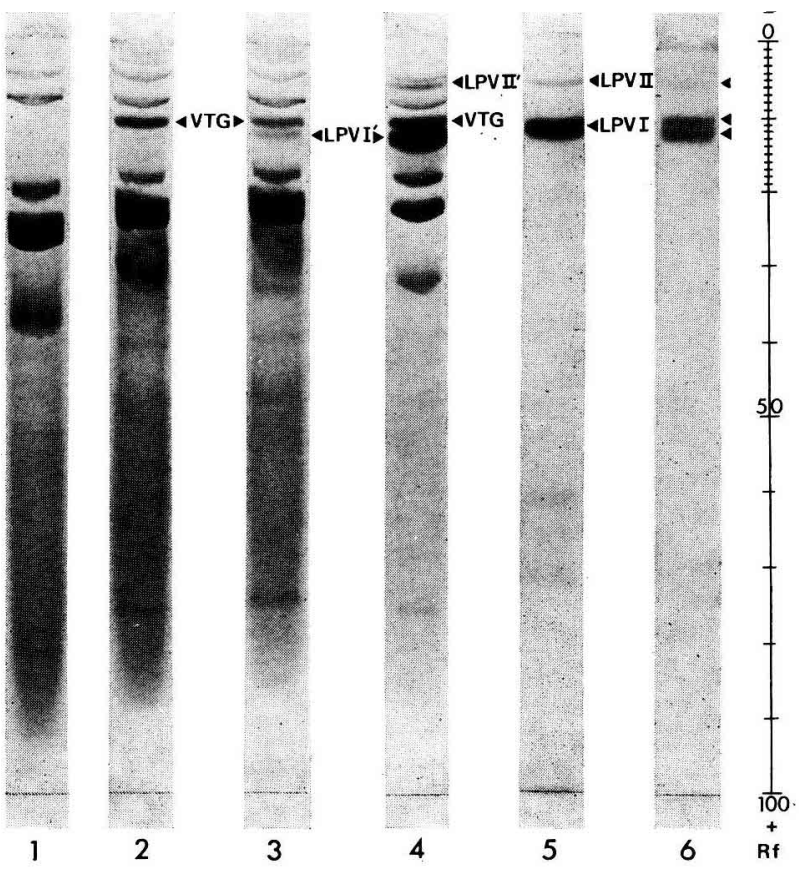

FIG. 2. - Polyacrylamide gel electrophoresis of hemolymph samples and homogenized ovaries of Orchestia gammarella (from Junera, Meusy and Croisille, 1974, modified). 1 : male hemolymph (no band in the VTG and LPV I-I' zone) ; 2 and 3 : hemolymph of females in reproduction raised with males (VTG present and sometimes weak LPV I') ; 4 : hemolymph of a female in reproduction raised alone (LPV I' band considerably intensified) ; 5 : vitellogenic ovary of a female raised with males (LPV I electrophoretic mobility is similar to that of the VTG) ; 6 : ovary of an isolated female ; ovary is being resorbed since no eggs were laid (LPV I is dividing). LPV I-I'-II-II' : lipovitellin I-I'-II-II'; VTG : vitellogenin. 


\section{Identification of vitellogenin and lipovitellins by polyacrylamide gel elec- trophoresis.}

After early work using agarose gel electrophoresis (Meusy, Charniaux-Cotton and Croisille, 1969 ; Meusy et al., 1970 ; Meusy, Junera and Croisille, 1971), we studied the hemolymph and ovary content of 0 . gammarella with polyacrylamide gel electrophoresis using the technique of Davis (1964) (Meusy, Junera and Croisille, 1974 ; Junera, Meusy and Croisille, 1974 ; Junera ef al., 1977b) (fig. 2).

Vitellogenin appeared on the hemolymph electrophoregrams of females in vitellogenesis as a violet band of low mobility, having no equivalent in the male. During vitellogenesis, two compounds in the ovary, both violet-colored and of low electrophoretic mobility, reacted as the vitellogenin with an antiserum raised against a total female extract and absorbed by a male extract. The most abundant of the two, which we called "lipovitellin I " (LPV I), had an electrophoretic behavior similar to that of vitellogenin. The other, of lower electrophoretic mobility, was called « lipovitellin II » (LPV II). During reproduction, if the females were not mated, they did not lay eggs and the vitellogenic oocytes were gradually resorbed. The band corresponding to LPV I was cleaved, producing a new band having a slightly higher mobility. The yolk components gradually passed into the hemolymph and soon appeared on the electrophoregrams ; we called those components LPV I' and LPV II' to recall their origin (fig. 2).

These mechanisms were analyzed in two types of experiments :

1) the females were isolated to prevent them from laying : the LPV I' band appeared (or intensified considerably), and the LPV II' band also became apparent after the yolk was resorbed (Junera et al., 1974) ;

2) ${ }^{3} \mathrm{H}$-leucine was injected into vitellogenic females: the vitellogenin, then the LPV I and LPV II became radioactive but not the LPV I' and the LPV II' (or the corresponding zone on the hemolymph electrophoregrams) ; the latter two did not become radioactive until the following molt and yolk resorption (Meusy and Junera, unpublished data).

Much work has been done on other crustaceans. We shall not mention those carried out by electrophoresis using media of mediocre resolution because their interest now is purely historical (see review in Gibert, 1972). From about 1970 on, the crustacean hemolymph and ovaries were studied by some authors using polyacrylamide gel electrophoresis. However, many of these only reported a large number of bands and speculated on the nature of the proteins and their physiological role. Polyacrylamide gel electrophoretic determination of a vitellogenin and a lipovitellin and their relation to vitellogenesis has been the object of some work on crustaceans (e.g. Fielder, Rao and Fingerman, 1971 in Uca pugilator ; Martin, 1972 in Carcinus maenas). Various authors have reported the existence of several female-specific proteins (Arcier, 1973 in Palaemon adspersus ; Picaud and Besse, 1973 in the isopod, Porcellio dilatatus), which, in some species, did not all seem to be involved in yolk formation (Romestand, 1971 in the isopod, Meinertia oestroides ; Picaud, 1971 in the isopod, Ligia oceanica). In 1974, Fyffe and O'Connor studying the crayfish, Procambarus sp., and using 
immunological analysis identified a protein separated by disc electrophoresis, common to the hemolymph and the vitellogenic ovaries. More recently, Picaud (1978a) contributed some details on "female-specific proteins" in the isopod, Porcellio dilatatus. According to him, the two fractions present in both the hemolymph and the yolk would have different origins : the first fraction - « vitellogenin 》- having a $M W=$ $3.77 \pm 0.67 \times 10^{5}$ and lower electrophoretic mobility would be of exogenous (extraovarian) origin, while the other - « vitellin " $\left(\mathrm{MW}=3.15 \pm 0.54 \times 10^{5}\right)$ - predominant in oocytes finishing vitellogenesis, would correspond to an endogenous protein, i.e. synthesized by the ovary and « possibly migrating under certain conditions into the hemolymph and accumulating there ". However, the confidence intervals given do not show a difference in $M W$ between the "vitellogenin » and the " vitellin », contrary to what Picaud reports in another publication (1978b). According to that author, this interpretation of the origin of the two fractions would be supported by the hemolymph electrophoregrams of ovariectomized females in which only the "vitellogenin » fraction was highly intensified. In our opinion, this result could be interpreted differently, i.e. the "vitellin » would not be of endogenous origin, but would derive from vitellogenin transformation by the oocyles during vitellogenesis. It would indeed be remarkable if, contrary to other crustaceans, most of the isopod yolk was of endogenous origin. Moreover, Picaud himself (1978b) showed the immunological identity of «vitellogenin » and "vitellin», thus making the divergentorigin hypothesis rather improbable.

\section{Immunological identity of serum vitellogenin and lipovitellin (or lipovitel- lins) of the yolk.}

Very early, authors comparing the electrophoretic pattern of female crustacean hemolymph and ovary during vitellogenesis noticed a protein having the same mobility (see review in Gibert, 1972). However, such an observation was not sufficient for identification. Kerr (1969) showed for the first time in a crustacean, the crab, Callinectes sapidus, that the lipoprotein composing most of the yolk was immunologically indistinguishable from a serum lipoprotein (vitellogenin). The same was found for the vitellogenin and the two lipovitellins of 0 . gammarella (Meusy, 1972 ; Croisille ef al., 1974). These results have also been extended to the decapods, Uca pugilator, Libinia emarginata (Wolin, Laufer and Albertini, 1973), Palaemon adspersus (Arcier and Tournamille, 1974) and Procambarus sp. (Fyffe and O'Connor, 1974), then to the isopod, Porcellio dilatatus (Picaud, 1978b). They confirmed data in the other main groups in which vitellogenin had been identified.

The direction of vitellogenin transit however remained a mystery. Ultrastructural observation favored ovarian uptake of vitellogenin from the hemolymph, but oniy data on the site of the synthesis of that complex, or at least proof of its extraovarian origin, could provide definitive data.

\section{Site of vitellogenin synthesis.}

The site of vitellogenin synthesis in crustaceans has not been clearly determined. Some authors, using old work on the transit of carotenoid pigments from the hepato- 
pancreas to the ovaries (e.g. Abeloos and Fischer, 1926), tended to conceive of the hepatopancreas as the organ of vitellogenin synthesis (Ceccaldi and Martin, 1969). Nothing however suggested that the vitellogenin protein fraction had the same origin as the carotenes associated with it. The common immunological identity of vitellogenin and a protein in a hepatopancreatic extract was reported in Uca pugilator and Libinia emarginata (Wolin, Laufer and Albertini, 1973). The significance of such a result was doubtful as the organ extract could have been contaminated by serum components and, unless extreme precautions were taken, would have been highly degraded by hepatopancreatic enzymes.

Kerr (1968) cultured different tissues and organs (muscle, heart, hepatopancreas, total hemolymph and serum) of the crab, Callinectes sapidus, in the presence of ${ }^{14} \mathrm{C}$-leucine and, using column chromatography and electrophoresis, analyzed the protein released in the medium. According to her, all the tissues cultured, except the serum, incorporated ${ }^{14} \mathrm{C}$-leucine, the total hemolymph being the most labelled. As 40 p. 100 of the total hemolymph activity was found in vitellogenin, Kerr suggested that the hemocytes might be the site of synthesis. To our knowledge, this result has never been confirmed, and the similar studies which we carried out in collaboration with Croisille and Junera (unpublished data) on $O$. gammarella were not conclusive. More recently Lui ef al. (1974, 1976, 1977) attempled to show that the ovaries of the crayfish, Procambarus sp., and the crab, Pachygrapsus crassipes, synthesized vitellogenin. They incubated the ovaries in a ${ }^{3} \mathrm{H}$-leucine medium or a mixture of tritiated amino acids for 30 or $48 \mathrm{hrs}$. After denaturation and electrophoresis of lipovitellin according to the technique of Weber and Osborn (1969), they demonstrated that radioactivity was present in the main polypeptide subunits of Cambarus and in all the three subunits of Pachygrapsus. Nevertheless, in spite of the large quantities of radioactivity introduced into the incubation medium, reaching, in one of the experiments, $500 \mu \mathrm{Ci}$ of ${ }^{3} \mathrm{H}$-leucine to a volume of 5 to $8 \mathrm{ml}$ of medium, and notwithstanding the rather long incubation time (18 to $48 \mathrm{hrs}$ ), lipovitellin radioactivity was extremely low. A quantitative comparison of in vitro with in vivo labelling in as similar conditions as possible would be interesting.

\section{Our studies on O. gammarella (unpublished data) showed that :}

- vitellogenic ovaries subsisted poorly when incubated in an isotonic saline medium as well as when cultured in Eagle's liquid medium or on a gelose medium, according to Berreur-Bonnenfant (1962) ;

- the distribution of radioactivity in the electrophoregrams of vitellogenic ovary extracts, incubated or cultured for one or more hours in a medium containing a labelled amino acid, was abnormal and differed from the in vivo distribution.

Moreover, we showed in O. gammarella that vitellogenin was synthesized outside the ovaries (Junera et al., 1977a). If females in reproduction were bilaterally ovariectomized, vitellogenin synthesis did not stop immediately, as would be the case if the ovaries were the site of synthesis; it only stopped 5 to 8 days after the operation for reasons which will be discussed further on (fig. 3). This result was, in our opinion, an absolute proof of the extraovarian synthesis of vitellogenin, but it did not demonstrate that the ovaries did not also synthesize it. The latter possibility however does 
not appear very probable. After the animal was injected with ${ }^{3} \mathrm{H}$-leucine, vitellogenin labelling clearly preceded that of the lipovitellins (Meusy and Junera, unpublished data).

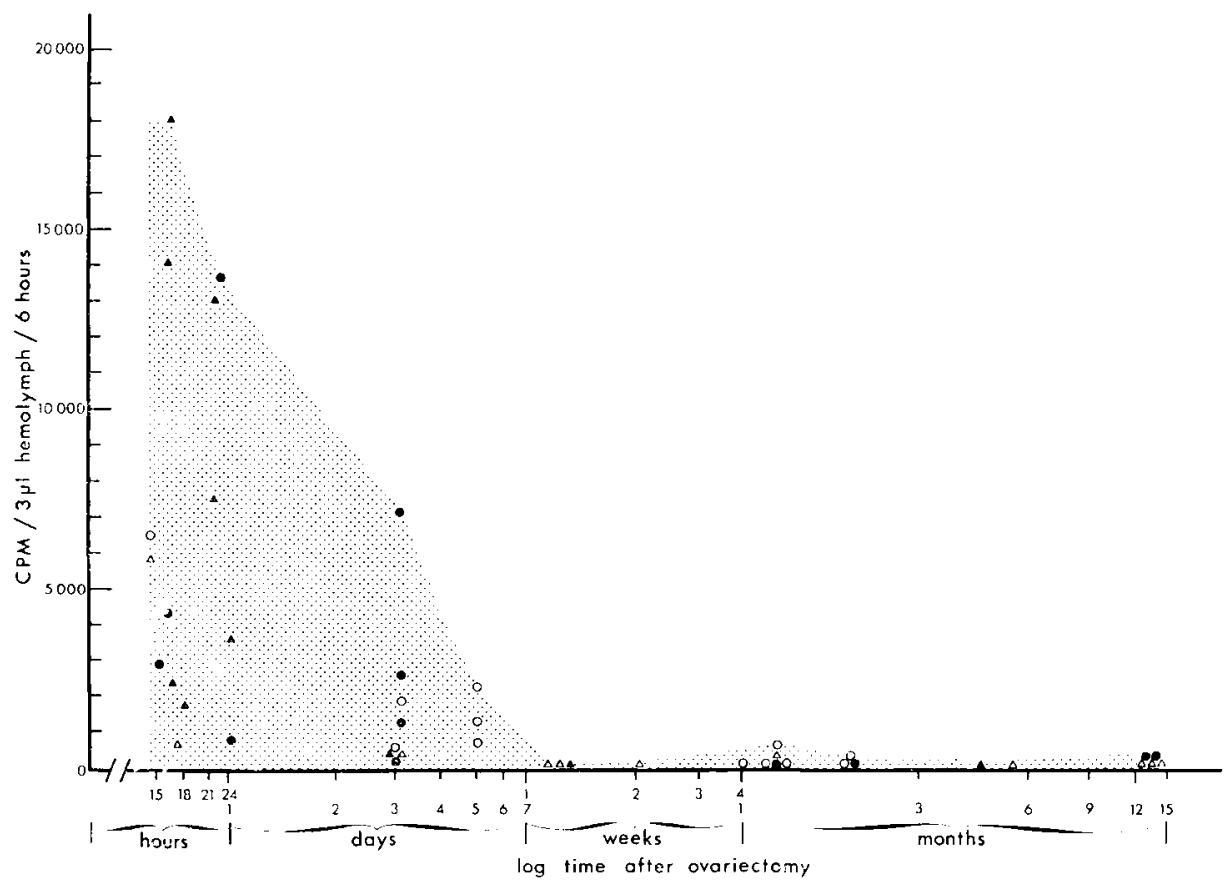

FIG. 3. - Effect of bilateral ovariectomy on vifellogenin synthesis in Orchestia gammarella (from Junera ef al., 1977a). The animals studied received a ${ }^{3} \mathrm{H}$-leucine injection $6 \mathrm{hrs}$ before the hemolymph was sampled. After disc-electrophoresis, vitellogenin radioactivity was measured and corrected to $3 \mu \mathrm{l}$ of hemolymph. The points all represent distinct animals studied at different molt stages. $(\Delta)$ : stage $C ;(\bullet)$ : stage $D_{0} ;(0)$ : stage $D_{1} ;(\bullet)$ : stage $D_{2}$.

In other groups, vitellogenin synthesis occurs outside the ovaries: in the liver of birds, amphibians and fish (e.g. Wallace, 1972 ; Wachsmuth and Jost, 1976) and in the fat body of insects (see review in Wyatt and Pan, 1978). In the cephalopod mollusc, Loligo peali, radioautographic investigations at the ultrastructural level suggest that yolk proteins are synthesized by the follicular syncytium (Selman and Wallace, 1978). Unless this study used antibodies, they could not have been conclusive or convincing. Among annelids, and especially in nereid worms, it was usually considered that vifellogenesis take place in an autonomous manner. Nevertheless, Fischer (1979) has recently demonstrated the occurrence of a vitellin-like antigen in the coelomic fluid of maturing Nereis virens females. It is an open question whether such protein originated from degenerating oocytes, or was really a vitellogenin synthesized outside the ovaries.

\section{Chemical nature and properties of vitellogenin and lipovitellins.}

Besides being a female-specific serum protein, which caused it to be designated as the "female protein fraction », early work on crustacean vitellogenin noted its 
low electrophoretic mobility (" proximal fraction », " slow fraction »). Moreover, the presence of prosthetic lipid (Sudan Black staining), carbohydrate (PAS-positiveness) and carotenoid (pigment extraction and absorption spectrum study) identified the vitellogenin as a «lipo-glyco-carotenoprotein » (e.g. Adiyodi in the crab, Paratelphusa hydrodromous, $1968 \mathrm{~b}$; Ceccaldi in the crab, Carcinus maenas, 1967 ; Kerr in the crab, Callinectes sapidus, 1969). The same was true of lipovitellin(s) which, depending on the author and the species, would include between 28 and 35 p. 100 of lipids (Wallace, Walker and Hauschka, 1967 ; Fyffe and $O^{\prime}$ Connor, 1974). In O. gammarella, lipid and carbohydrate groups were also observed (unpublished work). The carotenes gave a bright color to the vitellogenin and lipovitellins, varying with the species : e.g. violet in O. gammarella, green in the shrimp, Lysmata seficaudata, orange in the crab, Carcinus maenas. The ovaries quickly acquired the coloring because vitellogenin was massively sequestered at that time by the large oocytes. It was thus easy to distinguish a vitellogenic ovary from one which was not, depending on whether it was colored or whitish.

The MW of vitellogenin was reported for the first time in a crustacean, the amphipod, 0 . gammarella, by Junera et al. $(1977 \mathrm{~b})$ using the method of Hedrick and Smith (1968), and was found to be $3.97 \pm 0.28 \times 10^{5}$, or approximately $4 \times 10^{5}$. Lipovitellin I, the most abundant lipovitellin in the yolk of that species, had a MW of $3.48 \pm$ $0.24 \times 10^{5}$, or approximately $3.5 \times 10^{5}$; that of lipovitellin II was $4.98 \pm 0.38 \times 10^{5}$, or about $5 \times 10^{5}$. Finally, in the yolk resorbing females, lipovitellin I' in the hemolymph had a MW of $3.64 \pm 0.25 \times 10^{5}$, which was not significantly different from that of

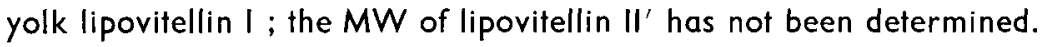

Statistical computation showed no difference in $\mathrm{MW}$ between vitellogenin and lipovitellin I, but the possibility should be kept in mind. On the other hand, lipovitellin II had a significantly higher MW.

It is interesting to note that when purified vitellogenin, lipovitellin I or $I^{\prime}$ was electrophoresed according to the method of Hedrick and Smith, a heavy type of MW similar to that of lipovitellin II, was obtained in addition to type I. Similarly, lipovitellin II gave a lighter MW form similar to that of the lipovitellins I-I'. There was thus a spontaneous transformation in vitro between heavy lipovitellin II and the lighter lipovitellin I, and an equilibrium was established between the two forms. It should also be noted that when a female in vitellogenesis was injected with ${ }^{3} \mathrm{H}$-leucine, the labelling ratio of lipovitellin II to lipovitellin I was about equal to the concentration ratio between those two complexes, or between 5 and 10 p. 100 (Junera ef al., 1977b). We do not yet know if the reciprocal transformation, lipovitellin I $\leftrightarrow$ lipovitellin II, and the equilibrium between the two forms were closely related to our experimental conditions, or if they also occurred in vivo. It must be remarked that the addition of EDTA $(10 \mathrm{mM})$ and of trasylol $(1.5 \mathrm{p} .100)$ to the buffer used for the hemolymph samples or the ovarian extracts did not change the results (unpublished data). Some seemingly analogous processes have been reported (Wallace, Walker and Hauschka, 1967 ; Gellissen et al., 1976).

The MW of the " ovoverdin » (lipovitellin) of lobster eggs was estimated from the sedimentation constant $\left(S_{20^{\circ}}=10.8\right)$ to be $3 \times 10^{5}$ (Wyckoff, 1937). More recently Ceccaldi, Cheesman and Zagalsky (1966) using filtration on Sephadex G 200 gel, evaluated the MW of the egg ovoverdin of the lobster. Homarus gammarus, to be 
$3.8 \times 10^{5}$. A mean MW of $3.5 \times 10^{5}$ was reported by Wallace, Walker and Hauschka (1967) for the lipovitellin of Pagurus pollicaris, Uca pugilator. Sesarma reticulatum, Libinia emarginata, Homarus americanus and Cancer irroratus (method of sedimentation rate determination combined with estimation of the coefficient of diffusion in an agarose column). Analytical ultracentrifugation of the lipovitellin of the crayfish, Procambarus sp., gave a higher MW of $5 \times 10^{5}$ (Fyffe and $O^{\prime}$ Connor, 1974). In the isopod, Porcellio dilatatus, Picaud (1978a), using the electrophoretic technique of Hedrick and Smith (1968), evaluated the MW of the vitellogenin to be $3.77 \pm 0.67 \times 10^{5}$ and that of "vitellin " at $3.15 \pm 0.54 \times 10^{5}$. Thus, the results obtained in various crustacean species are generally of the same order of magnitude as those found in amphibians, fish and birds.

The polypeptide subunits of the vitellogenin and lipovitellin of 0 . gammarella (Meusy and Junera, 1979) have been studied using the main principle of the method of Weber and Osborn (1969) (fig. 4). After denaturation by sodium dodecyl sulfate (SDS) and mercaptoethanol in the presence of dithiothreitol (DTT), the vitellogenin of 0. gammarella showed at least 8 to 11 components using SDS-acrylamide-gel electrophoresis; the MW of these components ranged between $0.31 \times 10^{5}$ and $2.35 \times 10^{5}$. During vitellogenesis, the transformation of vitellogenin into lipovitellins was accompanied by the gradual disappearance of the compounds of highest MW. The large number of components observed did not seem to be due to insufficient purification of the vitellogenin, incomplete denaturation or enzymatic degradation during treatment. It rather suggested :

1) either that the vitellogenin was composed of a complex of several proteins, or

2) that it was synthesized in a form including only two of the largest components or subunits, strictly speaking, having a MW $\simeq 2.35 \times 10^{5}$ and $2.17 \times 10^{5}$. These subunits would then undergo proteolytic cleavage. Thus, the vitellogenin peptidogram would be the expression of the subunit composition of both the native form and of molecules in transformation. This mechanism would continue during vitellogenesis,

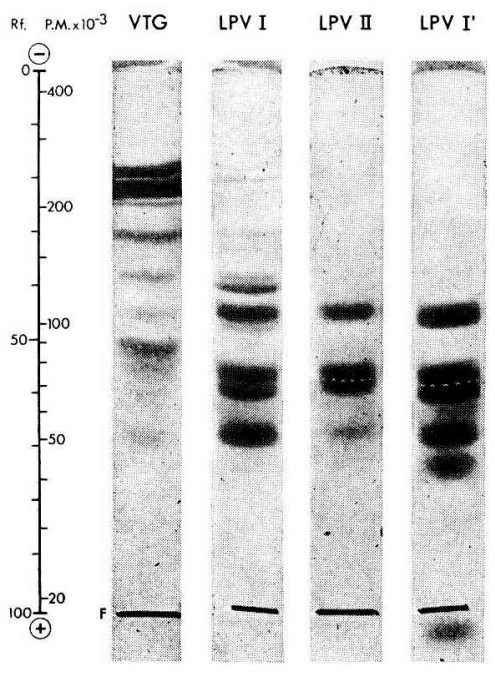

FIG. 4. - Vitellogenin and lipovitellin electrophoregrams of Orchestia gammarella in denaturing conditions (technique of Weber and Osborn, 1969) (from Meusy and Junera, 1979, modified). On the left : Rf and MW scale $\left(\mathrm{MW} \times 10^{-3}\right)$. $\mathrm{F}$ : front indicated by a metallic wire ; LPV I-I'-II : lipovitellin I-I'-II ; VTG : vitellogenin. 
vitellogenin transformation into lipovitellins thus leading to the almost complete disappearance of the heaviest elements. Radioactive labelling studies should determine if this hypothesis is correct.

To our knowledge, no other work on crustacean vitellogenin subunits has been reported. The lipovitellin of the crayfish, Procambarus sp., had 5 subunits (Lui and $O^{\prime}$ Connor, 1976) and that of the crab, Pachygrapsus crassipes, 3 « main » subunits (Lui and $O^{\prime}$ Connor, 1977).

The results on vitellogenin and « vitellin » in insects seem to vary widely with the species studied. Some authors, noting the large number of subunits, reported that the native form of vitellogenin had a very small number of high molecular weight polypeptides which underwent proteolytic cleavage before entering the oocytes (Koeppe and Ofengand, 1976 ; Chen, Strahlendorf and Wyatt, 1978). We have seen that this interpretation could also be applied to the vitellogenin of 0 . gammarella.

The amino acid composition of lipovitellin has been determined in some decapods (Zagalsky in Homarus gammarus and Cancer pagurus, 1972 ; Lui and $O^{\prime}$ Connor in Procambarus sp, and Pachygrapsus crassipes, 1977). Glutamic acid was one of the most abundant amino acids present along with serine, aspartic acid and leucine. Similar observations have been reported in insects, amphibians and birds. However, the sequences must differ since crossed immunological reactions were obtained only between phylogenetically close crustacean species (Croisille, Meusy and CharniauxCotton, 1970 ; Picaud, 1978b).

\section{Is vitellogenin transformed during vitellogenesis ?}

Many studies on amphibians have shown that the vitellogenin in the oocytes was split into a low MW phosphoprotein, phosvitin, and a high MW lipovitellin. No analogous transformation has been reported in crustaceans and insects. Many authors have noted that vitellogenin and lipovitellin were immunologically indistinguishable and that their molecular weight did not significantly differ in most species. Can it be concluded that vitellogenesis in the Arthropoda is a simple accumulation of the vitellogenin in specialized structures (yolk bodies and platelets) without the intervention of any chemical modification? This interpretation would seem premature. Besides the fact that we have shown two lipovitellins of different $M W$ in 0 . gammarella, the polypeptidic subunit composition of the vitellogenin and lipovitellins seemed to indicate chemical transformation. In effect, the heaviest subunits, probably corresponding to those of the native vitellogenin, gradually disappeared during vitellogenesis. It would be interesting to determine if there are enzymes in the yolk bodies and platelets which could cause such transformations. Acid phosphatase was detected in the yolk platelets of Drosophila melanogaster (Giorgi and Jacob, 1977), but it was not known if that enzyme acted during vitellogenesis or only during egg development.

Picaud (1978a) reporied a difference in the solubility of vitellogenin and « vitellin » at a low saline concentration in the isopod, Porcellio dilatatus; the "vitellin » was noted as being the more soluble. This author did not attempt to interpret this result.

Work is in progress in our laboratory which should soon provide an answer to this question. 


\section{Relation between vitellogenin synthesis, reproductive cycle and molt cycle.}

Vitellogenin appeared in 0 . gammarella females during the 7th, 8th and 9th intermolts after hatching (Junera, 1973). During sexual rest (between November and February in the Roscoff region), vitellogenesis (2nd vitellogenesis according to the terminology of Dhainaut and de Leersnyder, 1976 and Charniaux-Cotton, 1978) did not occur in the ovaries of 0 . gammarella females. Vitellogenin was often still detectable in the hemolymph, but its synthesis, studied by injecting a radioactive amino acid, ceased (Meusy, Junera and Croisille, 1974). The cerebral neurosecretory centers probably participate in the control mechanisms involved (see last chapter).

In O. gammarella vitellogenin synthesis was also related to the molt cycle. In this species, vitellogenesis occurs during an intermolt, egg laying following ecdysis. At the onset of intermolt (stages $A$ and $B$ according to the terminology of CharniauxCotton, 1957), vitellogenin synthesis siudied by injecting ${ }^{3} \mathrm{H}$-leucine and then counting the radioactivity present on the electrophoregram in the zone considered, was very reduced, if not nil. It became considerable at the beginning of stage $C$. i.e. the time when the largest oocytes commenced to massively sequester vitellogenin from the hemolymph by micropinocytosis, and, as a result, became increasingly violet-colored. At the end of vitellogenesis and the molt cycle (stage $D_{2}$ ), vitellogenin synthesis decreased (Meusy, Junera and Croisille, 1974). The relation of that synthesis to the molt, has not been reported in other crustaceans to our knowledge. We supposed that ecdysterone ( $\beta$-ecdysone) which controls molt might also be responsible for the variations observed, and we carried out experiments on this subject. Introducing $200 \mathrm{ng}$ of ecdysterone crystals for $1 \mathrm{mg}$ of animal fresh weight at the onset of the intermolt did not trigger vitellogenin synthesis, and when administered later, the hormone did not affect that synthesis rate (Blanchet, Junera and Meusy, 1975). On the other hand, the complementary operation in which the female $Y$-organs, generally considered as the source of the molting hormone (Chang and O'Connor, 1977) were cauterized, caused a depression of the synthesis in progress. Correlated to this, the operation arrested the growth of vitellogenic oocytes (Meusy, Blanchet and Junera, 1977). An arrest of vitellogenesis was also reported by Reidenbach (1971) after Y-ectomy of the isopod, Idotea balthica. Data on the crab, Carcinus maenas, are rather confused and contradictory (Arvy, Echalier and Gabe, 1954, 1956 ; Demeusy, 1959, 1962a, b). In Drosophila, quite similar results have been related by Handler and Postlethwait (1978). Those authors found that vitellogenin synthesis was reduced in isolated abdomens of Drosophila and that treatment by ecdysterone (or juvenile hormone analog) repaired this defect.

Our results were difficult to interpret. Ecdysterone appeared to be indispensable to normal vitellogenin synthesis, but supraphysiologic addition of it had no effect. It must be recalled that this hormone stimulates various metabolisms and that there is little chance it would specifically regulate vitellogenin synthesis. Moreover, Blanchet, Porcheron and Dray (1979) showed that the ecdysteroid content of females in reproduction and of those in sexual rest was not significantly different. Nevertheless, those authors found a higher ecdysteroid concentration in the vitellogenic ovaries than in the rest of the animal. Similar observations have been reported in Locusta migratoria (Lagueux, Hirn and Hoffmann, 1977). Nothing proved that those hormones 
female form) and spermatogenesis stopped, but the gonad did not become a functional ovary; at the most, several oocytes were seen which never developed. Some of the animals were studied up to $91 / 2$ months after the operation, but the vitellogenin never appeared spontaneously in the hemolymph; an ovary from a normal female had to be grafted (Meusy, Junera and Croisille, 1971). The grafted ovary carried out vitellogenesis in the host, as reported by Charniaux-Cotton (1957), while the vitellogenin became abundant.

We did the complementary experiment by bilaterally ovariectomizing some females in reproduction (fig. 5). After a maximum period of 5 to 8 days, no more newly synthesized vitellogenin was found in the hemolymph (fig. 3) (Junera ef al., 1977a). We thus concluded that the ovary produced a hormone regulating the synthesis of vitellogenin (or possibly its release in the hemolymph). The ovary itself could not thus be considered as the site of vitellogenin synthesis since bilateral ovariectomy did not cause immediate arrest of the synthesis. We proposed calling that hormone, never before reported in crustaceans, « vitellogenin-stimulating ovarian hormone » (VSOH). It is not known if the mechanism exists in all malacostracan crustaceans. In the isopod, Porcellio dilatatus, Picaud (1974) reported that ovariectomy led to vitellogenin accumulation in the hemolymph. Since no data on radioactive precursor incorporation were given, it was not known if vitellogenin synthesis decreased or eventually stopped after a shorter or a longer period. Our observations on 0 . gammarella had indicated that vitellogenin could remain in the hemolymph a long time without deteriorating or being eliminated.

Charniaux-Cotton (1952) showed that 0 . gammarella ovaries had a hormonal function : they controlled the presence of a permanent secondary sex character, the oostegites, fringed with juvenile setae. Moreover, only when the ovaries were in vitellogenesis did they induce long setae (" ovigerous setae ») to appear on the oostegites (Charniaux-Cotton, 1955, 1965). The question was : did the same ovarian hormone regulate both the vitellogenin and the ovigerous setae?

In the mosquito, Aedes aegypti, Hagedorn and Fallon (1973) showed that a blood meal released vitellogenin synthesis only in the presence of ovaries secreting a vitellogenin-stimulating hormone (VSH). However, those authors later assimilated that hormone to $\beta$-ecdysone (Hagedorn ef al., 1975); that would not be the case in 0 . gammarella, as noted above. In most insects, the mechanisms seemed to differ from those proposed for the mosquito: many authors showed that the juvenile hormone secreted by the corpora allata constituted the hormone stimulating the vitellogenin synthesis (see review in Hagedorn and Kunkel, 1979).

In the house cricket, Acheta domesticus, Bradley and Edwards (1978) reported that ovariectomy caused vitellogenin accumulation in the hemolymph, but that synthesis then slowed down.

In Drosophila Kambysellis (1977) succeeded, for the first time in an insect, in inducing vitellogenin synthesis in the male by grafting an ovary taken from a female after the larva had metamorphosed into pupa ; larval ovaries had no effect. Thus, Drosophila would have an « ovarian inducing agent», perhaps only secreted after hatching, which induced the synthesis. This interpretation has been challenged recently by Hagedorn and Kunkel (1979).

The ovarian graft in the male had no effect in other species : the cabbage white 
butterfly, Pieris brassicae (Lamy and Karlinsky, 1974), and the blowfly, Sarcophaga bullata (Huybrechts and de Loof, 1977). The ovaries played no role in either Leucophaea maderae (Koeppe and Ofengand, 1976) or Triatoma protracta (Mundall and Engelmann, 1977).

On the other hand, all authors agreed that $17 \beta$-estradiol (an ovarian inducing hormone as the VSOH of 0 . gammarella) triggered vitellogenin synthesis in male amphibians, fish and birds.

\section{Neurohormonal control of vitellogenin synthesis.}

The role of neurohormones in the control of vitellogenin synthesis in crustaceans is still practically unknown. It is probable that brain neurohormones are involved in the action of external factors such as temperature and photoperiod, which determine the annual period of sexual rest in many species of crustaceans (fig. 6).

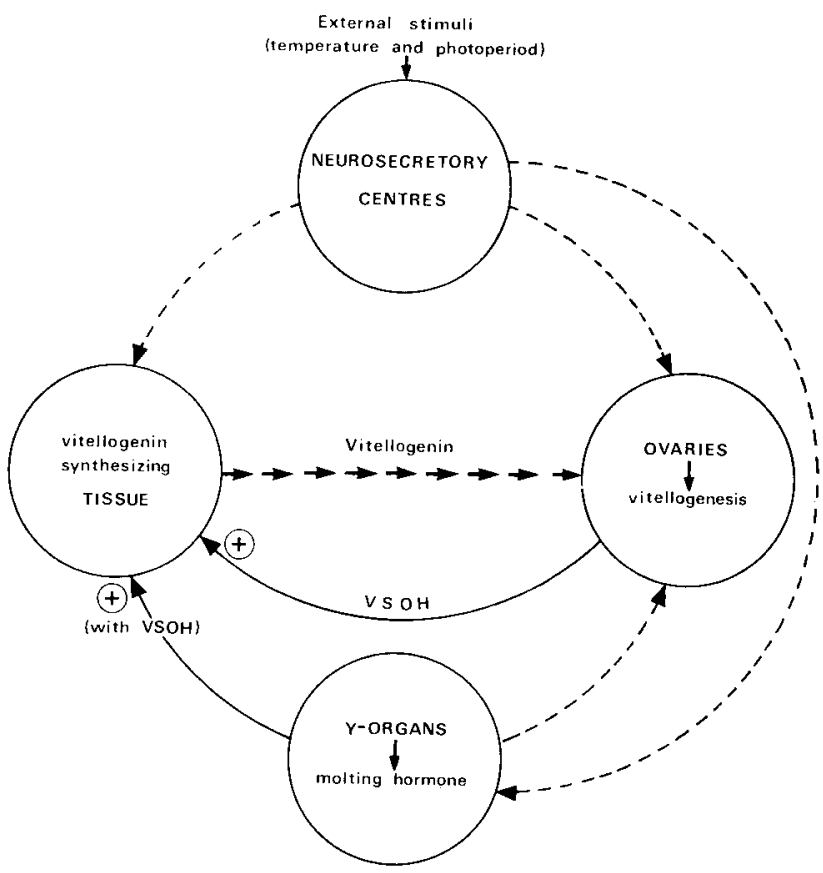

FIG. 6. - Diogram of hormonal control of vitellogenin synthesis in Orchestia gammarella. $\longrightarrow \rightarrow$ : demonstrated controls; $\rightarrow-\rightarrow$ : hypothetical controls.

The preliminary results in our laboratory obtained in collaboration with Blanchet and Junera seemed to indicate that the destruction of the protocerebron median region of 0 . gammarella females was followed by a significant decrease of vitellogenin synthesis. An effect of a different type was reported in the isopod, Ligia oceanica (Juchault et al., 1969 ; Mocquard ef al., 1969, 1971 ; Picaud, 1971), in which excision of the median area of the protocerebron caused an acceleration of vitellogenesis 
and molting rhythm, while in the males that operation induced a hermaphroditic physiology, characterized by the appearance of a substance resembling vitellogenin. It should be remarked that the protocerebron region in isopods probably cannot be anatomically and physiologically compared to the "corresponding "zone of the 0 . gammarella protocerebron.

The role of the $X$-organ-sinus gland system needs to be studied. The suppression of that system in decapods by complete excision of the ocular stalks triggered vitellogenesis or accelerated it in most species; it also seemed probable that action was related to an effect on vitellogenin synthesis. Moreover, Touir (1979) reported that the serum fraction of the female shrimp, Lysmata seticaudata, which he regarded as being the vitellogenin, was clearly intensified in the electrophoregrams after eyestalk ablation during sexual rest period.

Although more results were obtained on insects than on crustaceans, they were heterogeneous. Cerebral neurosecretory regulation might operate, at least in some species, via the corpora allata and juvenile hormone secretion (see Mundall and Engelmann, 1977 and their bibliography).

\section{Conclusions.}

Although some aspects of the data on crustaceans are limited, many similarities with models in other groups are apparent, permitting the following general definition of vitellogenin : vitellogenin is a high molecular weight, female-specific protein complex found during reproduction in the hemolymph/blood of Crustacea, Myriopoda, Insecta, Amphibia, birds and some fish ; it is synthesized outside the ovaries and used by the oocytes to constitute the yolk.

The term « vitellogenin 》 better describes this substance than the previous terms used in the literature since it suggests the basic role of the complex : participation in the genesis of the yolk.

As in the main groups cited, vitellogenin synthesis can be induced in the males of some crustacean species. In the amphipod, 0. gammarella, we have demonstrated a hormone which, like the estrogens in vertebrates, is of ovarian origin and controls vitellogenin synthesis (VSOH).

Lipovitellin(s) (or vitellin(s)) may be defined as a protein complex originating directly from the vitellogenin and constituting the main part of the protein yolk in the groups mentioned above. The ultrastructural study of crustacean vitellogenesis, as well as that of the correlative biochemical transformation of vitellogenin into lipovitellins, is in progress and has already shown important common points in the mechanisms involved.

Reçu en juin 1979.

Accepté en aout 1979.

\section{Références}

ABELOOS M., FISCHER E., 1926. Sur l'origine et les migrations des pigments carotinoïdes chez les Crustacés. C. R. Soc. Biol., 95, 383-384.

ADIYODI R. G., 1968a. Protein metabolism in relation to reproduction and moulting in the crab, Paratelphusa hydrodromous (Herbst) : Part I. - Electrophoretic studies on the mode of ufilization of soluble proteins during vitellogenesis. Indian J. exp. Biol., 6, 144-147. 
ADIYODI R. G., 1968b. Protein metabolism in relation to reproduction and moulting in the crab Parafelphusa hydrodromous. Part II. - Fate of conjugated proteins during vitellogenesis. Indian J. exp. Biol., 6, 200-203.

ARCIER J.-M., 1973. Etude de la composition protéique de l'hémolymphe des femelles chez Paloemon adspersus Rathke 1837 (Crustacé, Décapode, Natantia) ; ses rapports avec les cycles successifs de vitellogenèse. C. R. Acad. Sci., Paris, 276, sér. D, 2293-2296.

ARCIER J.-M., TOURNAMILLE J., 1974. Recherches immunochimiques sur les protéines de vitellogenèse chez Polaemon odspersus (Rathke, 1837) (Crustacés, Décapodes, Natantia). C. R. Acad. Sci. Paris, 278, sér. D, 495-498.

ARVY L., ECHALIER G., GABE M., 1954. Modifications de la gonade de Carcinides maenas L. (Crustacé Décapode) après ablation bilatérale de l'organe Y. C. R. Acad. Sci. Paris, 239, 1853-1855.

ARVY L., ECHALIER G., GABE M., 1956. Organe $Y$ et gonade chez Carcinides (Carcinus) maenas L. Ann. Sci. nat. Zool., 18, 263-267.

BALESDENT M.-L., 1965. Recherches sur la sexualifé ef le déferminisme des caractères sexuels d'Asellus aquaticus Linné (Crustacé Isopode). Bull. Acad. Soc. Lorraine Sci., 5, 1-231. (Th. Doct. Etat, Univ. Nancy, 1964).

BALINSKY B. I., DEVIS R. J., 1963. Origin and differentiation of cytoplasmic structures in the oocytes of Xenopus laevis. Acta embryol. morphol. exp., 6, 55-108.

BEAMS H. W., KESSEL R. G., 1962. Intracisternal granules of endoplasmic reficulum in the crayfish oocyte. J. Cell Biol., 13, 158-162.

BEAMS H. W., KESSEL R. G., 1963. Electron microscope studies on developing crayfish oocytes with special reference to the origin of yolk. J. Cell Biol., 18, 621-650.

BERREUR-BONNENFANT J., 1962. Essai de culture in vitro de gonades de Crustacés. Bull. Soc. Zool. Fr., 4, 377.

BESSE G., MOCQUARD J.-P., 1968. Ełude par électrophorèse des quantités relatives des protéines de l'hémolymphe d'individus normaux et de femelles castrées chez deux Crustacés Isopodes : Porcellio dilatatus Brandt et Ligia oceanica L. C. R. Acod. Sci. Paris, 267, sér. D, 2017-2019.

BESSE G., JUCHAULT P., LEGRAND J.-J., MOCQUARD, J.-P., 1970. Modification de l'électrophorégramme de l'hémolymphe des Oniscoīdes (Crustacés Isopodes) par action de l'hormone androgène. C. R. Acad. Sci. Paris, série D, 270, 3276-3279.

BLANCHET M.-F., JUNERA H., MEUSY J.-J., 1975. Mue et vitellogenèse chez Orchestia gammarella Pallas (Crustacé Amphipode) : étude de la synthèse de la fraction protéique femelle après introduction d'ecdystérone. Experientia, 31, 865-867.

BLANCHET M. F., PORCHERON P., DRAY F., 1979. Variations du taux des ecdystéroïdes au cours des cycles de mue chez le Crustacé Amphipode Orchestia gammarellus. Int. J. Invertebr. Reprod., 1, 133-139.

BRADLEY J. T., EDWARDS J. S., 1978. Yolk proteins in the house cricket, Achefo domesticus : identification, characterization and effect of ovariectomy upon their synthesis. J. exp. Zool., 204, 239-248.

BUSSON-MABILLOT S., 1969. Données récentes sur la vitellogenèse. Ann. Biol., 8, 199-228.

CECCALDI H. J., 1967. Transport des pigments caroténoïdes dans l'hémolymphe de Carcinus moenas Linné. C. R. Acad. Sci. Paris, série D, 161, 1105-1110.

CECCALDI H. J., CHEESMAN D. F., ZAGALSKY P. F., 1966. Quelques propriétés el caractéristiques de l'ovoverdine. C. R. Soc. Biol., 160, 587-590.

CECCALDI H. J., MARTIN J.-L. M., 1969. Evolution des protéines de l'hémolymphe chez Carcinus maenas L. durant l'ovogenèse. C. R. Soc. Biol., 163, 2638-2641.

CHANG E. S., O'CONNOR J. D., 1977. Secretion of $\alpha$-ecdysone by crab Y-organs in vitro. Proc. nat. Acad. Sci. USA, 74, 615-618.

CHARNIAUX H., 1952. Castration chirurgicale chez un Crustacé Amphipode : Orchestia gammarella Pallas et déterminisme des caractères sexuels secondaires. Premiers résultats. C. R. Acad. Sci. Paris, 234, 2570-2572.

CHARNIAUX-COTTON H., 1955. Le déterminisme hormonal des caractères sexuels d'Orchestia gammarella (Crustacé Amphipode). C. R. Acad. Sci. Paris, 240, 1487-1489.

CHARNIAUX-COTTON H., 1957. Croissance, régénération et déterminisme endocrinien des caractères sexuels d'Orchestia gammarella Pallas (Crustacé Amphipode. Ann. Sci. nat., 19, 411 560. 
CHARNIAUX-COTTON H., 1965. Hormonal control of sex differentiation in Invertebrates, 701740. In HAAN R. L., URSPRUNG H., Organogenesis. Holt. Rinehart and Winston, New York.

CHARNIAUX-COTTON H., 1978. L'ovogenèse, la vitellogénine et leur contrôle chez le Crustacé Amphipode Orchestia gammarellus (Pallas). Comparaison avec d'autres Malacosiracés. Arch. Zool. exp. Gén., 119, 365-397.

CHEN T. T., STRAHLENDORF P. W., WYATT G. R., 1978. Vitellin and vitellogenin from locusts (Locusta migratoria). Properties and post-translational modification in the fat body. J. biol. Chem., 253, 5325-5331.

CROISILLE Y., MEUSY J.-J., CHARNIAUX-COTTON H., 1970. Ełude immunochimique chez différents Crustacés supérieurs de la spécificité de la « fraction protéique femelle » de l'hémolymphe. C. R. Acad. Sci. Paris, série D, 271, 527-529.

CROISILLE Y., JUNERA H., MEUSY J.-J., CHARNIAUX-COTTON H., 1974. The female-specific protein (Vitellogenic protein) in Crustacea with particular reference to Orchestio gammarello (Amphipoda). Amer. Zool., 14, 1219-1228.

DAVIS B. J., 1964. Disc electrophoresis. Il. Method and application to human serum proteins. Ann. N. Y. Acad. Sci., 121, 404-427.

DEMEUSY N., 1959. Pédoncules oculaires, glande de mue et appareil génifal de Carcinus maenas $L$. C. R. Acad. Sci. Paris, 248, 2652-2654.

DEMEUSY N., 1962a. Observations sur la maturation ovarienne du Crabe Carcinus maenas L. après ablation des glandes de mue chez les femelles adultes. Premiers résultats. C. R. Acad. Sci. Paris, 255, 3062-3064.

DEMEUSY N., 1962b. Rôle de la glande de mue dans l'évolution ovarienne du Crabe Carcinus maenas Linné. Cah. Biol. mar., 3, 37-56.

DESCOUTURELLE G., FRENTZ R., 1967. Ełude par électrophorèse et immunoélectrophorèse des proféines d'extraits totaux et de l'hémolymphe d'Afyaephyra desmaresti Millet. Influence de l'ablation des pédoncules oculaires. Bull. Soc. Sci. Nancy, 6, 259-270.

DHAINAUT A., DE LEERSNYDER M., 1976a. Etude cytochimique et ultrastructurale de l'évolution ovocytaire du crabe Eriocheir sinensis. I. Ovogenèse naturelle. Arch. Biol., 87. 261-282.

DHAINAUT A., DE LEERSNYDER M., 1976b. Etude cyłochimique ef ultrastructurale de l'évolution ovocytaire du crabe Eriocheir sinensis. Il. Ovogenèse après ablation des pédoncules oculaires. Arch. Biol., 87, 283-302.

EURENIUS L., 1973. An electron microscope study on the developing oocytes of the crab Cancer pagurus L. with special reference to yolk formation (Crustacea). Z. Morph. Tiere, 75, 243254.

FIELDER D. R., RAO K. R., FINGERMAN M., 1971. A female-limited lipoprotein and the diversity of hemocyanin components in the dimorphic variants of the fiddler crab, Uca pugilator, as revealed by disc electrophoresis. Comp. Biochem. Physiol., 39B, 291-297.

FISCHER A., 1979. A vitellin-like antigen in the coelomic fluid of maturing Nereis virens females. Naturwissenschaften, 66, 316-317.

FRENTZ R., 1960. Contribution à l'étude biochimique du milieu intérieur de Carcinus maenas Linné. Bull. Soc. Sci. Nancy, nlle série, 19, 1-176.

FYFFE W. E., O'CONNOR J. D., 1974. Characterization and quantification of a crustacean lipovitellin. Comp. Biochem. Physiol., 47B, 851-867.

GANION L. R., KESSEL R. G., 1972. Intracellular synthesis, transport, and packing of proteinaceous yolk in oocytes of Orconectes immunis. J. Cell Biol., 52, 420-437.

GELLISSEN G., WAJC E., COHEN E., HEMMERICH H., APPLEBAUM S. W., FLOSSDORF J., 1976. Purification and properties of oocyte vitellin from the migratory locust. J. comp. Physiol., 108, 287-301.

GIBERT J., 1972. Synthèse bibliographique des recherches électrophorétiques sur les protéines des Crustacés. Ann. Biol., 11, 305-327.

GIORGI F., JACOB J., 1977. Recent findings in oogenesis of Drosophila melanogasfer. Ill. Lysosomes and yolk platelets. J. Embryol. exp. Morph., 39, 45-57.

HAGEDORN H. H., FALLON A. M., 1973. Ovarian control of vitellogenin synthesis by the fat body in Aedes aegypti. Nature, 244, 103-105.

HAGEDORN H. H., KUNKEL J. G., 1979. Vitellogenin and vitellin in insects. Ann. Rev. Entomol., 24, 475-505. 
HAGEDORN H. H., O'CONNOR J. D., FUCHS M. S., SAGE B., SCHLAEGER D. A., BOHM M. K., 1975. The ovary as a source of $\alpha$-ecdysone in an adult mosquito. Proc. nat. Acad. Sci., USA, 72, 3255-3259.

HANDLER A. M., POSTLETHWAIT J. H., 1978. Regulation of vitellogenin synthesis in Drosophila by ecdysterone and juvenile hormone. J. Exper. Zool., 206, 247-254.

HEDRICK J. L., SMITH A. J., 1968. Size and charge isomer separation and estimation of molecular weights of proteins by disc gel electrophoresis. Arch. Biochem. Biophys., 126, 155-164.

HINSCH G. W., CONE M. V., 1969. Ultrastructural observations of vitellogenin in the spider crab, Libinia emarginata L. J. Cell Biol., 40, 336-342.

HUYBRECHTS R., DE LOOF A., 1977. Induction of vitellogenin synthesis in male Sarcophaga bullata by ecdysterone. J. Insect Physiol., 23, 1359-1362.

JUCHAULT P., BESSE G., LEGRAND J.-J., MOCQUARD J.-P., 1969. Analyse des contrôles multiples exercés par le protocérébron de Ligia oceanica $L$. Contrôle de la physiologie sexuelle mâle. C. R. Acad. Sci. Paris, série D, 268, 2605-2607.

JUNERA H., 1973. Recherches sur l'apparition de la «fraction protéique femelle » dans l'hémolymphe et les modalités de l'établissement de la puberté chez les femelles d'Orchestia gammarella Pallas (Crustacé Amphipode). C. R. Acad. Sci. Paris, sér. D, 277, 1213-1216.

JUNERA H., MEUSY J.-J., CROISILLE Y., 1974. Etude comparée de la « fraction protéique femelle » dans l'hémolymphe et dans l'ovaire du Crustacé Amphipode Orchestia gammarella Pallas par électrophorèse en gel de polyacrylamide. C. R. Acad. Sci. Paris, 278, sér. D, 655658.

JUNERA H., ZERBIB C., MARTIN M., MEUSY J.-J., 1977a. Evidence for control of vitellogenin synthesis by an ovarian hormone in Orchestia gammarella (Pallas), Crustacea ; Amphipoda. Gen. comp. Endocrinol., 31, 457-462.

JUNERA H., MARTIN M., SOLARI A., MEUSY J.-J., 1977b. Détermination du poids moléculaire de la vitellogénine et des lipovitellines d'Orchestia gammarella, Crustacé Amphipode. C. R. Acad. Sci. Paris, 285, sér. D, 909-912.

KAMBYSELLIS M. P., 1977. Genetic and hormonal regulation of vitellogenesis in Drosophila. Amer. Zool., 17, 535-549.

KERR M. S., 1968. Protein synthesis by hemocytes of Callinectes sapidus : A study of in vitro incorporaion of ${ }^{14} \mathrm{C}$-leucine. J. Cell Biol., 39, 72a-73a.

KERR M. S., 1969. The hemolymph proteins of the blue crab, Callinectes sapidus. II. A lipoprotein serologically identical to oocyte lipovitellin. Develop. Biol., 20, 1-17.

KESSEL R. G., 1968a. Mechanisms of protein yolk synthesis and deposition in crustacean oocytes. Z. Zellforsch., 89, 17-38.

KESSEL R. G., 1968b. The permeability of the crayfish oocyte-follicle complex as studied with peroxydase as a tracer. J. Cell Biol., 38, 169-170.

KOEPPE J. K., OFENGAND J., 1976. Juvenile hormone induced biosynthesis of vitellogenin in Leucophaea maderae from large precursor polypeptides, 486-504. In L. I. GILBERT The juvenile hormones, Plenum Press, New York.

LAGUEUX M., HIRN M., HOFFMANN J., 1977. Ecdysone during ovarian development in Locusta migratorio. J. Insect Physiol., 23, 109-119.

LAMY M., KARLINSKY A., 1974. Vitellogenèse protéique en milieu mâle chez la Piéride du chou, Pieris brassicae L. (Lépidoptère). C. R. Acad. Sci. Paris, 278, sér. D, 91-94.

LANZAVECCHIA G., 1961. The formation of yolk in frog oocytes. Proc. europ. Reg. Conf. electron. Microsc., Delft, 746-749.

LUI C. W., SAGE B. A., O'CONNOR J. D., 1974. Biosynthesis of lipovitellin by the crustacean ovary. J. exp. Zool., 188, 289-296.

LUI C. W., O'CONNOR J. D., 1976. Biosynthesis of lipovitellin by the crustacean ovary. Il. Characferization of and in vitro incorporation of amino acids into the purified subunits. J. exp. Zool., 195, 41-52.

LUI C. W., O'CONNOR J. D., 1977. Biosynthesis of crustacean lipovitellin. III. The incorporation of labeled amino acids into the purified lipovitellin of the crab Pachygrapsus crassipes. J. exp. Zool., 199, 105-108.

MARTIN J.-L. M., 1972. Evolution des protéines de l'ovaire chez Carcinus maenas L. femelle durant l'ovogenèse. Tethys, 3, 251-254. 
MEUSY J.-J., 1963. La gamétogenèse d'Orchestia gammarella P., Crustacé Amphipode. Bull. Soc. Zool., 88, 197-220.

MEUSY J.-J., 1972. La gamétogenèse et la fraction protéique de l'hémolymphe spécifique du sexe femelle chez quelques Crustacés supérieurs : étude descriptive et rôle des glandes androgènes. Th. Doct. Etat, Univ. Paris VI, no CNRS : AO 6583.

MEUSY J.-J., 1978. La formation du vitellus chez les Crustacés. La Recherche, 9, 388-389.

MEUSY J.-J., BLANCHET M.-F., JUNERA H., 1977. Mue et vitellogenèse chez le Crustacé Amphipode Orchestia gammarella Pallas. II. Etude de la synthèse de la vitellogénine (« fraction protéique femelle » de l'hémolymphe) après destruction des organes $Y$. Gen. comp. Endocrinol., 33, 35-40.

MEUSY J.-J., CHARNIAUX-COTTON H., CROISILLE Y., 1969. Etude par électrophorèse chez Orchestia gammarella (Pallas) et Orchestio mediterranea Costa (Crustacés Amphipodes) des protéines de l'hémolymphe : comparaison entre les mâles, les femelles et les intersexués. C. R. Acod. Sci. Poris, 269, sér. D, 741-743.

MEUSY J.-J., GINSBURGER-VOGEL T., CHARNIAUX-COTTON H., CROISILLE Y., 1970. Recherche par électrophorèse de la «fraction protéique femelle dans l'hémolymphe des femelles d'Orchestia gammarella P. (Crustacé Amphipode) masculinisées par greffe d'une glande androgène. C. R. Acad. Sci. Paris, 270, sér. D, 1385-1387.

MEUSY J.-J., JUNERA H., 1979. Analyse comparative de la composition en sous-unités polypeptidiques de la vitellogénine et des lipovitellines du Crustacé Amphipode Orchestia gammarello (Pallas). C. R. Acad. Sci., Paris, 288, sér. D, 1415-1418.

MEUSY J.-J., JUNERA H., CROISILLE Y., 1971. Recherche de la « fraction protéique femelle » chez les Crustacés Amphipodes Orchestia gammarella ayant subi une inversion expérimentale du sexe. C. R. Acad. Sci. Paris, 273, sér. D, 592-594.

MEUSY J.-J., JUNERA H., CROISILLE Y., 1974. Données sur la synthèse de la fraction protéique femelle chez Orchestia gammarella Pallas (Crustacé Amphipode) au cours de l'intermue ef chez les femelles en repos sexuel. C. R. Acad. Sci. Paris, 279, sér. D, 587-590.

MOCQUARD J.-P., BESSE G., JUCHAULT P., 1969. Analyse des contrôles multiples exercés par le protocérébron de Ligia oceanica $L$. Contrôle de la croissance et de la mue. C. R. Acad. Sci. Paris, série D, 269, 78-81.

MOCQUARD J.-P., BESSE G., JUCHAULT P., LEGRAND J.-J., MAISSIAT J., NOULIN G., 1971 . Contribution à l'analyse du contrôle neurohormonal de la croissance, de la mue et de la physiologie sexuelle mâle et femelle chez l'Oniscoïde Ligia oceanica L. (Crustacé, Isopode). Ann. Embryol. Morph., 4, 45-63.

MUNDALL E., ENGELMANN F., 1977. Endocrine control of vitellogenin synthesis and vifellogenesis in Triatoma protracta. J. Insect Physiol., 23, 825-836.

PICAUD J.-L., 1971. Mise en évidence de protéines de type femelle et d'une protéine spécifique du fonctionnement ovarien par électrophorèse sur gel de polyacrylamide de l'hémolymphe et de broyats d'ovaires de Ligio oceanica L. C. R. Acad. Sci. Paris, 273, sér. D, 12141216.

PICAUD J.-L., 1974. Contribution à l'étude par électrophorèse des protéines des Oniscoïdes. Th. $3^{\text {e }}$ cycle, Poitiers.

PICAUD J.-L., 1976. Modifications des protéinogrammes de l'hémolymphe provoquées par certains types d'intersexualité chez les Oniscoïdes Ligia oceanica L. et Armadillidium vulgare Latr. (Crustacés Isopodes). C. R. Acad. Sci. Paris, 283, sér. D, 1421-1424.

PICAUD J.-L., 1978a. Contribution à l'étude des propriétés physico-chimiques des protéines spécifiques femelles de Porcellio dilatatus Brandt (Crustacé Isopode, Oniscoïde). C. R. Sac. Biol., 172, 299-303.

PICAUD J.-L., 1978b. Parentés antigéniques des protéines spécifiques femelles chez quelques Crustacés Isopodes. C. R. Soc. Biol., 172, 320-324.

PICAUD J.-L., BESSE G., 1973. Les protéines de l'hémolymphe et de l'ovaire de Porcellio dilatatus $\mathrm{Br}$. : leurs variations en fonction de la vitellogenèse. C. R. Acad. Sci. Paris, 276, sér. D, $2207-$ 2210.

REIDENBACH J.-M., 1971. Les mécanismes endocriniens dans le contrôle de la différenciation du sexe, la physiologie sexuelle ef la mue chez le Crustacé Isopode marin : Idotea balthica (Pallas). Th. Doct. Etat, Univ. de Nancy I, no CNRS : AO-4874. 
ROMESTAND B., 1971. Etude électrophorétique des protéines de l'hémolymphe chez l'Isopode Cymothoïdae Meinertia œstroides (Risso) en rapport avec les différentes phases de l'évolution sexuelle. C. R. Acad. Sci. Paris, 272, sér. D, 2242-2245.

SELMAN K., WALLACE R. A., 1978. An autoradiographic study of vitellogenesis in the squid, Loligo peali. Tissue Cell, 10, 599-608.

TELFER W., 1954. Immunological studies of insect metamorphosis. II. The role of a sex-limited blood protein in egg formation by the cecropia silkworm. J. gen. Physiol., 37, 539-558.

TOUIR A., 1979. Données nouvelles concernont le contrôle du sexe et de l'activité génitale chez les Crustacés Décapodes Natantia, en particulier chez la Crevefte hermaphrodite protérandrique Lysmata seticaudata Risso. Th. Doct., Etat, Univ. Paris VI.

WALLACE R. A., 1972. The role of protein uptake in vertebrate oocyte growth and yolk formation, 339-359. In BIGGERS J. D., SCHUETZ A. W., Oogenesis. Univ. Park Press, Baltimore.

WALLACE R. A., WALKER S. L., HAUSCHKA P. V., 1967. Crustacean lipovitellin. Isolation and characterization of the major high-density lipoprotein from the eggs of Decapods. Biochemistry, 6, 1582-1590.

WARD R. T., 1962. Origin of protein in R. pipiens. II. Electron microscopical and observations of young and mature oocytes. J. Cell Biol., 14, 349-351.

WARD R. T., 1964. Dual mechanisms for the formation of yolk platelets in Rana pipiens. J. Cell Biol., 23, 100A.

WASCHSMUTH E. D., JOST J.-P., 1976. Localization of vitellogenin and serum albumin in hepatic parenchymal cells of normal and estradiol-treated immature chickens. Biochim. biophys. Acta, 437, 454-461.

WEBER K., OSBORN M., 1969. The reliability of molecular weight determinations by dodecyl sulfate-polyacrylamide gel electrophoresis. J. biol. Chem., 244, 4406-4412.

WOLIN E. M., LAUFER H., ALBERTINI D. F., 1973. Uptake of the yolk protein, lipovitellin, by developing crustacean oocytes. Develop. Biol., 35, 160-170.

WYATT G. R., PAN M. L., 1978. Insect plasma proteins. Ann. Rev. Biochem., 47, 779-817.

WYCKOFF R. W. G., 1937. The sedimentation constant of ovoverdin. Science, 86, 311-312.

ZAGALSKY P. F., 1972. Comparative studies on the amino acid compositions of some carotenoidcontaining lipoglycoproteins and a glycoprotein from the eggs and ovaries of certain aquatic invertebrates. Comp. Biochem. Physiol., 41B, 385-395.

ZERBIB C., 1973. Contribution à l'étude ultrastructurale de l'ovocyte chez le Crustacé Amphipode Orchestia gammarella Pallas. C. R. Acad. Sci. Paris, 277, sér. D, 1209-1212.

ZERBIB C., 1976. Nature chimique des enclaves vitellines de l'ovocyte du Crustacé Amphipode Orchestia gammarellus (Pallas). Ann. Histochim., 21, 279-285.

ZERBIB C., 1977. Endocytose ovocytaire chez le Crustacé Amphipode Orchestia gammarellus (Pallas). Démonstration par la peroxydase. C. R. Acad. Sci., Paris, 284, sér. D, 757-759.

ZERBIB C., 1978. Ovogenèse chez le Crustacé Amphipode Orchestia gammarellus (Pallas) : contribution à son étude cytologique ef physiologique. Th. Doct. Etat, Univ. Paris VI.

ZERBIB C., 1979. Etude ultrastructurale de l'ovocyte en vitellogenèse chez les écrevisses Astacus astacus et A. Jeptodactylus. Int. J. Invertebr. Reprod., 1, 289-295. 